\title{
Effects of Ammonia and Lactate on Hybridoma Growth, Metabolism, and Antibody Production
}

\author{
Sadettin S. Ozturk, ${ }^{*}$ Mark R. Riley, and Bernhard O. Palsson \\ Cellular Biotechnology Laboratory, Department of Chemical Engineering, \\ University of Michigan Ann Arbor, Michigan 48109
}

Received April 30, 1991/Accepted September 13, 1991

The influence of ammonia and lactate on cell growth, metabolic, and antibody production rates was investigated for murine hybridoma cell line 163.4 G5.3 during batch culture. The specific growth rate was reduced by one-half in the presence of an initial ammonia concentration of $4 \mathrm{mM}$. Increasing ammonia levels accelerated glucose and glutamine consumption, decreased ammonia yield from glutamine, and increased alanine yield from glutamine. Although the amount of antibody produced decreased with increasing ammonia concentration, the specific antibody productivity remained relatively constant around a value of $0.22 \mathrm{pg} / \mathrm{cell}-\mathrm{h}$. The specific growth rate was reduced by one-half at an initial lactate concentration of $55 \mathrm{~m} M$. Although specific glucose and glutamine uptake rates were increased at high lactate concentrations, they showed a decrease after making corrections for medium osmolarity. The yield coefficient of lactate from glucose decreased at high lactate concentrations. A similar decrease was observed for the ammonia yield coefficient from glutamine. At elevated lactate concentrations, specific antibody productivities increased, possibly due to the increase in medium osmolarity. The specific oxygen uptake rate was insensitive to ammonia and lactate concentrations. Addition of ammonia and lactate increased the calculated metabolic energy production of the cells. At high ammonia and lactate, the contribution of glycolysis to total energy production increased. Decreasing external $\mathrm{pH}$ and increasing ammonia concentrations caused cytoplasmic acidification. Effect of lactate on intracellular $\mathrm{pH}$ was insignificant, whereas increasing osmolarity caused cytoplasmic alkalinization.

Key words: hybridoma growth - lactate - antibody production - ammonia

\section{INTRODUCTION}

Cost-effective production of antibodies requires high numbers of viable hybridoma cells. The cell concentration obtained in bioreactors is determined, in part, by the supply of nutrients. Waste products also control cell concentration by inhibiting cell growth. Ammonia and lactate are major waste products of glucose and glutamine metabolism, ${ }^{8}$ and their presence has been demonstrated to diminish growth of mammalian cells and to influence protein production.

Ammonia, a major inhibitory waste product of glutamine metabolism in mammalian cell cultures, is released by chemical decomposition of glutamine and by

\footnotetext{
* To whom all correspondence should be addressed at Verax Corporation, 6 Etna Road, Lebanon, NH 03766.
}

metabolic deamination of glutamine to glutamate and by the conversion of glutamate to $\alpha$-ketoglutarate. Concentration of ammonia in cell culture is influenced by the mode of reactor operation, cell and glutamine concentrations, and cellular activities. Although ammonia concentrations of $2-5 \mathrm{mM}$ are typical in batch cultures, ${ }^{12}$ they can be higher in glutamine-limited fedbatch reactors where glutamine is added into the reactor continually, leading to more ammonia accumulation.

The influence of ammonia concentration on hybridoma cell growth and monoclonal antibody production has been reported for both batch and continuous culture. Table I summarizes these studies and the kinetic parameters that have been investigated as a function of ammonia concentration. Most of these studies emphasized the influence of ammonia on cell growth. Although ammonia inhibited cell growth in all these studies, the sensitivity of the growth rate to ammonia concentration varied among the cell lines used. Ammonia concentration in the range of 2 to $10 \mathrm{mM}$ was observed to inhibit cell growth by $50 \%$ (Table I).

The effects of elevated ammonia concentrations on metabolic rates and cell productivity have been studied less extensively. Reuveny et al. observed a decrease in final antibody concentration in batch culture; however, they did not evaluate the specific antibody production rates. ${ }^{15}$ Glacken et al. reported a decrease in specific antibody production in response to increasing ammonia levels. ${ }^{5}$ However, McQueen and Bailey did not observe any change in specific antibody production as a result of ammonia addition. ${ }^{9-11}$ Miller et al. have studied the response of hybridoma cell line AB2-143.2 to ammonia pulse and step changes in continuous culture, ${ }^{12}$ including the metabolic rates of glucose, glutamine, lactate, ammonia, oxygen, and alanine. McQueen and Bailey also studied the effects of ammonia on cell metabolism. ${ }^{9}$ Their data were summarized in terms of yield coefficients rather than specific rates. Studying the effects of ammonia on intracellular $\mathrm{pH}, \mathrm{McQueen}$ and Bailey related the metabolic changes due to ammonia addition to a decrease in intracellular $\mathrm{pH} .{ }^{10,11}$

Lactate is mainly produced from glucose metabolism but can also be produced in small amounts from glutamine. ${ }^{26}$ The concentration of lactate depends on sev- 
Table I. Studies on the effect of ammonia on hybridoma cell growth, metabolism, and antibody production.

\begin{tabular}{|c|c|c|c|c|}
\hline Cell line & $\begin{array}{l}\text { Variables } \\
\text { investigated }\end{array}$ & $\begin{array}{c}\text { Kinetic } \\
\text { parameters } \\
\text { determined }\end{array}$ & $\begin{array}{l}{\left[\mathrm{NH}_{4}{ }^{+}\right] \text {where }} \\
\text { cell growth rate } \\
\text { reduced to } \\
50 \% \text { of maximum } \\
(\mathrm{m} M)\end{array}$ & Reference \\
\hline $\begin{array}{l}\text { Mouse hybridoma } \\
\text { CRL-1606 }\end{array}$ & $\begin{array}{l}\text { Cell growth } \\
\text { Antibody production }\end{array}$ & $\mu$ & 5 & $\begin{array}{c}\text { Glacken }^{5} \\
1987\end{array}$ \\
\hline $\begin{array}{l}\text { Mouse hybridoma } \\
\text { VII H-8 }\end{array}$ & $\begin{array}{l}\text { Cell growth } \\
\text { Antibody production }\end{array}$ & $\mu$ & 3 & $\begin{array}{l}\text { Reuveny }^{15} \\
\text { et al, } 1986\end{array}$ \\
\hline $\begin{array}{l}\text { Mouse hybridoma } \\
\text { cell line } 321\end{array}$ & Cell growth & & $\sim 4$ & $\begin{array}{l}\text { Thorpe } e^{22} \\
\text { et al, } 1987\end{array}$ \\
\hline $\begin{array}{l}\text { Mouse hybridoma } \\
\text { AB2-143.2 }\end{array}$ & $\begin{array}{l}\text { Cell growth } \\
\text { Glucose, glutamine } \\
\text { Lactate, ammonia } \\
\text { Alanine } \\
\text { Oxygen uptake }\end{array}$ & $\begin{array}{l}\mu \\
q_{\mathrm{Glu}}, q_{\mathrm{Gln}} \\
p_{\mathrm{Lac}}, p_{\mathrm{NH}_{4}} \\
q_{\mathrm{Ala}} \\
q_{\mathrm{O}_{2}}\end{array}$ & & $\begin{array}{l}\text { Miller }^{12} \\
\quad \text { et al, } 1988\end{array}$ \\
\hline $\begin{array}{l}\text { Mouse hybridoma } \\
\text { SB-4082 }\end{array}$ & Cell growth & $\mu$ & 1.8 & $\begin{array}{l}\text { Truskey }^{23} \\
\text { et al, } 1990\end{array}$ \\
\hline $\begin{array}{l}\text { Mouse hybridoma } \\
\text { ATCC TIB } 131\end{array}$ & $\begin{array}{l}\text { Cell growth } \\
\text { Glucose, glutamine } \\
\text { Lactate, ammonia } \\
\text { Intracellular pH } \\
\text { Antibody production }\end{array}$ & $\begin{array}{l}\text { Yield coefficients for } \\
\text { cell and metabolites }\end{array}$ & $\sim 10$ & $\begin{array}{l}\text { McQueen }^{\text {"I }} \\
\text { and Bailey } \\
1990\end{array}$ \\
\hline $\begin{array}{l}\text { Mouse hybridoma } \\
\text { 167.4G5.3 }\end{array}$ & $\begin{array}{l}\text { Cell growth and death } \\
\text { Glucose, glutamine } \\
\text { Lactate, ammonia } \\
\text { Amino acids } \\
\text { Antibody production } \\
\text { Intracellular pH } \\
\text { Oxygen uptake } \\
\text { Energy production }\end{array}$ & $\begin{array}{l}\mu, k_{d} \\
q_{\mathrm{Giu}}, q_{\mathrm{Gln}} \\
p_{\mathrm{Lac}}, p_{\mathrm{NH}_{4}} \\
q_{\mathrm{AA}} \\
q_{\mathrm{MAb}} \\
q_{\mathrm{O}_{2}} \\
q_{\mathrm{ATP}}\end{array}$ & 4 & This work \\
\hline
\end{tabular}

eral factors, including glucose concentration, cellular activity, and bioreactor operation. In the batch mode, lactate concentration can be as high as $35 \mathrm{mM} .{ }^{12}$ Lactate was reported to inhibit cell growth in systems without $\mathrm{pH}$ control, and the inhibition was attributed to media acidification. ${ }^{4}$ Growth may be limited by lactate even at constant $\mathrm{pH}$. Several studies have been reported in the literature for the effects of lactate on hybridoma cell growth, metabolism, and antibody production (Table II). Cell growth was the main parameter investigated in these studies. For CRL-1606 hybridoma cells, no significant lactate inhibition was observed at $40 \mathrm{~m} M$ of lactate. ${ }^{5}$ Stimulation of hybridoma cell (VII H-8) growth by lactate concentrations up to $22 \mathrm{mM}$ has been reported, followed by growth inhibition above $28 \mathrm{mM}$ lactate. ${ }^{15}$ Thorpe et al. ${ }^{22}$ and Miller et al. ${ }^{12}$ have not seen any inhibition of lactate on cell growth over the range of lactate concentration considered. The influence of lactate on cell metabolism and antibody productivity has not been thoroughly studied. Only Glacken et al. have reported influence of lactate on antibody production. ${ }^{5}$ Miller et al. observed almost no change in metabolic rates when lactate concentration was changed from $25 \mathrm{mM}$ to $44 \mathrm{mM}$.

Detailed kinetic studies are needed for characterization and optimization of hybridoma cell culture bioreactors. It is clear from Tables I and II that the previous reports on the influence of ammonia and lactate on hybridoma growth, metabolism, and antibody productiv- ity are limited in their scope. Most studies to date have focused on inhibition of cell growth. Previous studies offered some kinetic data on selected metabolites and specific antibody production rates. We have performed a comprehensive kinetic study on hybridoma cell cultures. Previously we have reported the effects of serum, dissolved oxygen, $\mathrm{pH}$, and osmolarity on these variables. ${ }^{17-20}$ In the present work, we extend our kinetic studies to the effects of ammonia and lactate. The action of these metabolic by-products were quantified in terms of specific cell growth and death rates, metabolic rates for glucose, lactate, glutamine, ammonia, and amino acids, and specific antibody production rates. We also present the regulation of intracellular $\mathrm{pH}$ and energy metabolism in the presence of these metabolic by-products.

\section{MATERIALS AND METHODS}

\section{Cell Culture and Maintenance}

Murine hybridoma cell line (167.4G5.3) was provided by Dr. Latham Claflin from the Medical Center at The University of Michigan. ${ }^{2,17}$ The cells were maintained in $75-\mathrm{cm}^{2}$ plastic T-flasks (Bellco) at $5 \% \mathrm{CO}_{2}$ atmosphere and $37^{\circ} \mathrm{C}$ in a humidified incubator (VWR Scientific). Iscove's modified Dulbecco's medium (IMDM, from Gibco) was used with 5\% fetal bovine serum (FBS from 
Table II. Studies on the effect of lactate on hybridoma cell growth, metabolism, and antibody production.

\begin{tabular}{|c|c|c|c|c|}
\hline Cell line & $\begin{array}{c}\text { Variables } \\
\text { investigated }\end{array}$ & $\begin{array}{c}\text { Kinetic } \\
\text { parameters } \\
\text { determined }\end{array}$ & $\begin{array}{l}\text { [Lactate] where } \\
\text { cell growth rate } \\
\text { reduced to } \\
50 \% \text { of maximum } \\
(\mathrm{m} M)\end{array}$ & Reference \\
\hline $\begin{array}{l}\text { Mouse hybridoma } \\
\text { CRL-1606 }\end{array}$ & $\begin{array}{l}\text { Cell growth } \\
\text { Antibody production }\end{array}$ & $\mu$ & 40 & $\begin{array}{c}\text { Glacken }^{5} \\
1987\end{array}$ \\
\hline $\begin{array}{l}\text { Mouse hybridoma } \\
\text { VII H-8 }\end{array}$ & $\begin{array}{l}\text { Cell growth } \\
\text { Antibody production }\end{array}$ & $\mu$ & $>22$ & $\begin{array}{l}\text { Reuveny }^{15} \\
\text { et al, } 1987\end{array}$ \\
\hline $\begin{array}{l}\text { Mouse hybridoma } \\
\text { cell line } 321\end{array}$ & Cell growth & & $\begin{array}{l}\text { No inhibition } \\
\text { up to } 10 \mathrm{~m} M\end{array}$ & $\begin{array}{l}\text { Thorpe } \\
\text { et al, } 1987\end{array}$ \\
\hline $\begin{array}{l}\text { Mouse hybridoma } \\
\text { AB2-143.2 }\end{array}$ & $\begin{array}{l}\text { Cell growth } \\
\text { Glucose, glutamine } \\
\text { Lactate, ammonia } \\
\text { Alanine } \\
\text { Oxygen uptake }\end{array}$ & $\begin{array}{l}\mu \\
q_{\mathrm{Glu}}, q_{\mathrm{Gln}} \\
p_{\mathrm{Lac}}, p_{\mathrm{NH}_{4}}+ \\
q_{\mathrm{Ala}} \\
q_{\mathrm{O}_{2}}\end{array}$ & $\begin{array}{l}\text { No inhibition } \\
\text { up to } 40 \mathrm{~m} M\end{array}$ & $\begin{array}{l}\text { Miller }^{12} \\
\quad \text { et al, } 1988\end{array}$ \\
\hline $\begin{array}{l}\text { Mouse hybridoma } \\
167.4 \mathrm{G} 5.3\end{array}$ & $\begin{array}{l}\text { Cell growth and death } \\
\text { Glucose, glutamine } \\
\text { Lactate, ammonia } \\
\text { Antibody production } \\
\text { Intracellular } \mathrm{pH} \\
\text { Oxygen uptake } \\
\text { Energy production }\end{array}$ & $\begin{array}{l}\mu, k_{d} \\
q_{\mathrm{Glu}}, q_{\mathrm{Gln}} \\
p_{\mathrm{Lac}}, p_{\mathrm{NH}_{4}} \\
q_{\mathrm{MAb}} \\
q_{\mathrm{O}_{2}} \\
q_{\mathrm{ATP}}\end{array}$ & 55 & This work \\
\hline
\end{tabular}

Gibco) supplemented with 100 units/mL potassium penicillin $\mathrm{G}$, and $100 \mu \mathrm{g} / \mathrm{mL}$ streptomycin sulfate (Sigma). The medium was buffered with $36 \mathrm{~m} M$ bicarbonate and $25 \mathrm{~m} M$ Hepes buffers.

\section{Effects of Ammonia and Lactate}

Ammonium chloride (Sigma) was dissolved in IMDM containing 5\% FBS at five different concentrations: 0 , $1.25,2.5,3.75$, and $5 \mathrm{mM}$. The initial $\mathrm{pH}$ was adjusted to 7.4 by the addition of sodium bicarbonate (Sigma) at room temperature. The media was supplemented with 100 units $/ \mathrm{mL}$ potassium penicillin $\mathrm{G}$, and $100 \mu \mathrm{g} / \mathrm{mL}$ streptomycin sulfate. Cells were inoculated into $75-\mathrm{cm}^{2}$ T-flasks (Bellco) at a cell concentration of $4 \times 10^{4}$ cells/mL containing $50 \mathrm{~mL}$ of media with different ammonia levels. Duplicate flasks were cultivated at $5 \%$ $\mathrm{CO}_{2}$ atmosphere and $37^{\circ} \mathrm{C}$ in the incubator.

Cells were cultured in IMDM with 5\% FBS in the presence of various lactate concentrations. Lactic acid (Sigma) was dissolved in IMDM and neutralized using $\mathrm{NaOH}$ (Sigma). The initial $\mathrm{pH}$ of the medium was adjusted to 7.4 by the addition of sodium bicarbonate (Sigma) at room temperature. Four lactate concentrations were used: $0,23,46$, and $69 \mathrm{mM}$. Then $5 \% \mathrm{FBS}$, 100 units $/ \mathrm{mL}$ potassium penicillin $G$ and $100 \mathrm{mg} / \mathrm{mL}$ streptomycin sulfate were added to each media. Cells were cultured in T-flasks as described above for the ammonia experiments.

\section{Analytical Methods}

A 1-mL sample was taken twice daily during the exponential growth phase and once daily during the death phase. Viable and dead cells were counted with use of a hemacytometer and differentiated by the trypan blue exclusion technique. The supernatants were stored at $-80^{\circ} \mathrm{C}$ for subsequent analysis of metabolite and monoclonal antibody concentrations.

Each sample was measured concurrently for glucose and lactate concentrations with the use of a model 2000 glucose/L-lactate analyzer (Yellow Springs Instruments, Yellow Springs, Ohio). The ammonia concentration was measured with a gas sensing electrode (Orion, Boston, MA) as described earlier. ${ }^{21}$ Amino acids were quantified using high-performance liquid chromatography (HPLC). ${ }^{17}$ The IgG $_{1}$ antibody was quantified using an enzyme-linked immunosorbent assay (ELISA) as described earlier. ${ }^{17}$ Media osmolarities were measured with an osmometer (Osmette, model 2007, Precision Systems, Natick, MA).

\section{Measurement of Oxygen Uptake Rates}

Oxygen uptake rates were measured in a respirometer (Yellow Springs) during the exponential growth phase. A 4-mL sample was placed into the sample chamber and agitated at $37^{\circ} \mathrm{C}$. The dissolved oxygen probe was inserted on the top of the sample, thus eliminating the gas phase. The decrease in dissolved oxygen concentration was recorded and was converted to cell specific uptake rates with known viable cell concentrations in the sample chamber.

\section{Measurement of Intracellular pH}

Intracellular $\mathrm{pH}$ measurements were carried out using a fluorescent dye and the method of Moolenaar et al. modified for cell suspensions. ${ }^{13}$ Upon cell entry, the ester BCECF/AM $\left[2^{\prime}, 7^{\prime}\right.$-bis(carboxyethyl)-5(6')-carboxy- 
fluorescein pentaacetoxymethyl] is converted to the fluorescent acid conjugate BCECF. The emission intensity of BCECF varies directly with $\mathrm{pH}$ and thus can be used to determine intracellular $\mathrm{pH}$. The BCECF/AM (Calbiochem Corp., San Diego, CA) was stored in DMSO at $-20^{\circ} \mathrm{C}$ as a $1 \mathrm{~m} M$ stock solution.

Cells were washed and resuspended in a HBS buffer adjusted to $\mathrm{pH} 7.20(140 \mathrm{~m} M \mathrm{NaCl}, 5 \mathrm{~m} M \mathrm{KCl}, 2 \mathrm{~m} M$ $\mathrm{CaCl}_{2}, 1 \mathrm{~m} M \mathrm{MgCl}_{2}, 10 \mathrm{~m} M$ Hepes, $10 \mathrm{~m} M$ glucose) at a density of $10^{7}$ cells $/ \mathrm{mL}$. Special care was taken during procedures to maintain cell viabilities of greater than $90 \%$. The BCECF/AM was added to give a final concentration of $10 \mu M$ in the cell suspension. Following a 1 -h incubation at $37^{\circ} \mathrm{C}$ with continuous mixing, the BCECF-loaded cells were washed and diluted 1:10 in four-sided, $1-\mathrm{cm}$ curvettes containing $1.8 \mathrm{~mL}$ of either calibration or experimental buffers.

The fluorescence measurements were carried out in a fluorescence spectrophotometer (Hitachi, F-2000, Tokyo, Japan). Excitation was achieved by a Xenon lamp set at $500 \mathrm{~nm}$ and the $530-\mathrm{nm}$ emission was recorded. Since the emission intensity of the trapped dye varies with $\mathrm{pH}$, intracellular $\mathrm{pH}$ can be determined using a calibration curve. For calibration, the BCECF/ AM-loaded cells were suspended in calibration buffers (150 $\mathrm{mM} \mathrm{KCl}$ and $10 \mathrm{~m} M$ Hepes) adjusted to different $\mathrm{pH}$ values. Nigericin (Calbiochem, San Diego, CA), an ionophore, was used to shift the intracellular $\mathrm{pH}$ to that of the respective buffer. Here, $3 \mu \mathrm{L}$ of a nigericin $(5 \mu \mathrm{g} / \mathrm{mL}$ ) stock solution (ethanol) was added and the cell suspensions allowed to equilibrate at $37^{\circ} \mathrm{C}$ for $10 \mathrm{~min}$. Emission intensity readings then were recorded. The composition of the experimental buffer, unlike the calibration buffer, is as follows: $140 \mathrm{~m} M \mathrm{NaCl}, 5 \mathrm{~m} M$ $\mathrm{KCl}, 2 \mathrm{~m} M \mathrm{CaCl}_{2}, 1 \mathrm{~m} M \mathrm{MgCl}_{2}, 10 \mathrm{~m} M$ Hepes buffer, and $10 \mathrm{~m} M$ glucose.

\section{Evaluation of Kinetic Parameters}

The kinetic parameters were evaluated in the exponential phase by the techniques described earlier. ${ }^{17-20}$ The standard deviation on the kinetic parameters calculated from duplicate experiments was less than $15 \%$.

\section{Estimation of ATP Production Rates}

Production rate of ATP was estimated using the lactate production and oxygen consumption rates following the procedure of previous investigators ${ }^{5,12}$ :

$$
q_{\mathrm{ATP}}=q_{\mathrm{Lac}}+6 q_{\mathrm{O}_{2}}
$$

where $q_{\mathrm{ATP}}, q_{\mathrm{Lac}}$, and $q_{\mathrm{O}_{2}}$ are the production rates of ATP, lactate, and oxygen, respectively. The limitation of this equation was discussed earlier. ${ }^{17-20}$ The term $q_{\text {Lac }}$ corresponds to the contribution of glycolysis and the term $6 q_{\mathrm{O}_{2}}$ corresponds to the contribution of oxidative phosphorylation.

\section{RESULTS}

\section{Effects of Ammonia}

Hybridoma cells 167.4 G5.3 grew in the presence of initial ammonia concentrations up to $3.75 \mathrm{mM}$ (Fig. 1), but at $5 \mathrm{~m} M$ ammonia no growth was observed. Cells grew exponentially at first; then a decline phase was established for all of the cultures (Fig. 1A). The batches with initial ammonia concentrations of 2.5 and $3.75 \mathrm{mM}$ showed a slight lag phase on the first day. Cell growth ceased in all of the cultures by the depletion of glutamine (Fig. 1D). Cell viabilities decreased with time in all the cultures and accelerated sharply during the decline phase (Fig. 1B). Initially, the drop in viability for batches containing $3.75 \mathrm{~m} M$ ammonia was more rapid, but with time these cultures actually displayed higher viabilities. About $75 \%$ of the glucose was consumed, producing primarily lactate (Fig. 1C). Glutamine was depleted and ammonia produced in all the cultures (Fig. 1D).

\section{Cell Growth}

Added ammonia inhibited cell growth over the concentration ranges used in this study, as seen from Fig. 1A. The calculated exponential phase growth rates were lowered as a result of inhibition by ammonia (Fig. 2A). The inhibition of growth by ammonia followed a similar pattern, as observed by previous investigators. ${ }^{5,23}$ These two reports related the growth rate to initial ammonia concentration by a second-order inhibition model:

$$
\mu=\frac{\mu_{0}}{1+\frac{\left[\mathrm{NH}_{4}^{+}\right]^{2}}{K_{a}}}
$$

where $\mu$ and $\mu_{0}$ are the growth rates in the presence and absence of external ammonia, respectively; $\left[\mathrm{NH}_{4}{ }^{+}\right]$ is the initial ammonia concentration; and $K_{a}$ is the inhibition constant. The square root of $K_{a}$ corresponds to the ammonia concentration at which the specific growth rate decreases by $50 \%$.

Our data could be described by Equation (2). Numerical values of $\mu_{0}=0.037 \mathrm{~h}^{-1}$ and $K_{a}=24 \mathrm{~m} M^{2}$ were obtained with a regression coefficient of $r^{2}=0.94$. The solid line in Figure $2 \mathrm{~A}$ is calculated using these numerical values. Interestingly, the specific death rates evaluated in the exponential phase did not change with ammonia concentration and remained at a value of $k_{d}=0.0043 \mathrm{~h}^{-1}$. Maximum viable and total cells decreased with increasing ammonia concentration, as presented in Fig. 2B.

\section{Cell Metabolism}

Metabolic consumption and production rates were calculated for glucose, glutamine, lactate, ammonia, and 

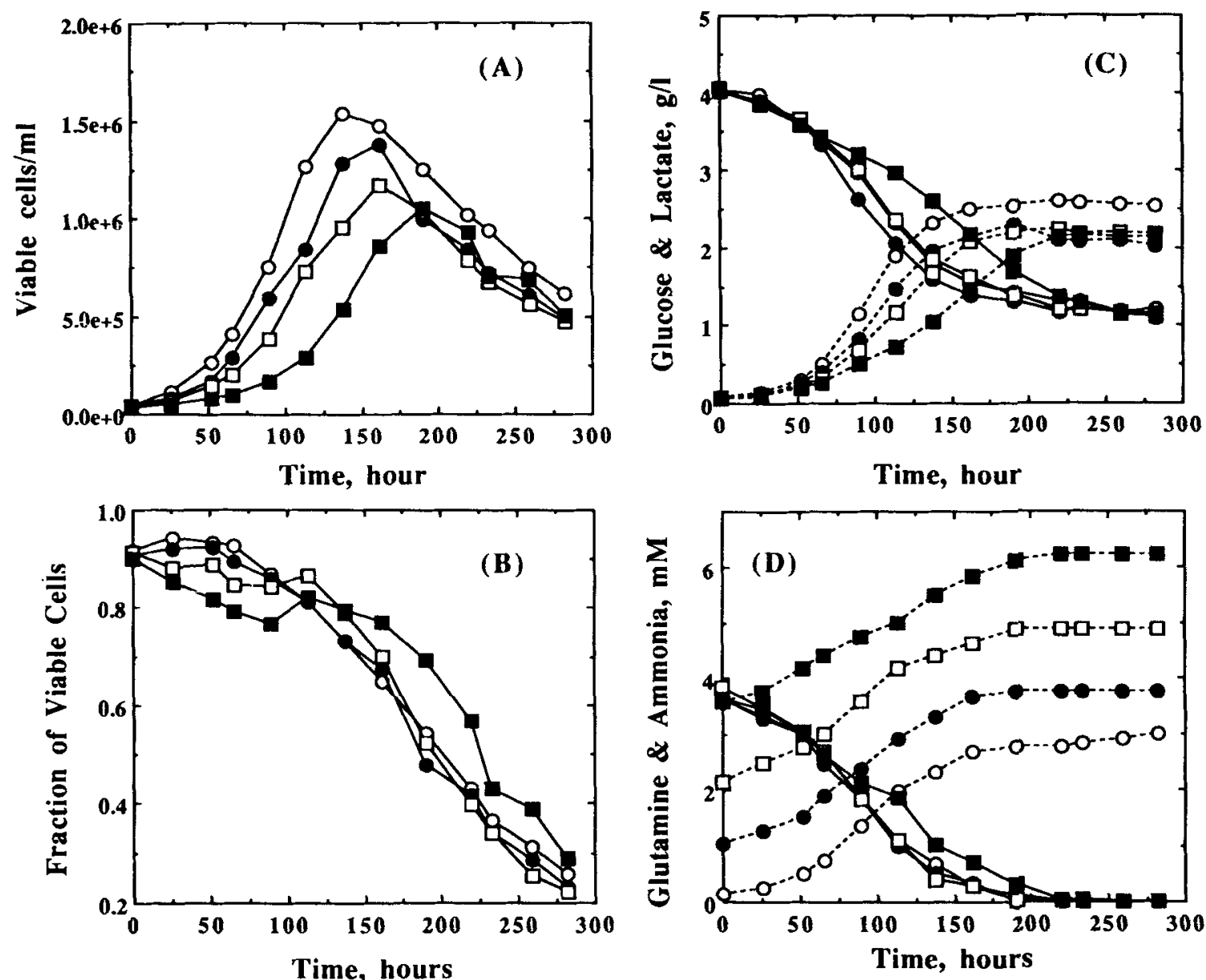

Figure 1. Influence of ammonia concentration: (A) viable cell concentrations; (B) cell viability; (C) glucose (solid line) and lactate (dashed line) metabolism; (D) glutamine (solid line) and ammonia (dashed line) concentrations. The initial ammonia concentrations: $0 \mathrm{~m} M(0), 1.25 \mathrm{~m} M(\bullet), 2.5 \mathrm{~m} M(\square)$, and $3.75 \mathrm{~m} M(\square)$.

amino acids using the data obtained during exponential growth. Specific rates of glucose and glutamine utilization as well as those for lactate and ammonia production increased with increasing ammonia concentration. The consumption rates of glucose and glutamine are presented in Table III. About a twofold increase in these rates was observed in cultures containing initially $3.75 \mathrm{~m} M$ of ammonia over those that had no ammonia added. The production rates of lactate and ammonia were also enhanced by the presence of ammonia. The yield coefficients of ammonia from glutamine and lactate from glucose decreased about $15 \%$ with an increase in the initial ammonia concentration from zero to $3.75 \mathrm{~m} M$ (Table III).

Amino acid consumption and production rates are summarized in Table IV. Glutamate, serine, glycine, and alanine were produced, and all other amino acids were consumed. Amino acid consumption and production rates were increased by the addition of ammonia, and the rates were higher for alanine, valine, isoleucine, leucine, and lysine. The consumption and production rates of these amino acids were doubled by the increase of initial ammonia concentration from zero to $3.75 \mathrm{mM}$. The increase in the amino acid consumption and production rates were parallel to the glutamine con- sumption rate as they increased at higher ammonia concentrations by the same magnitude. Only serine, arginine, alanine, and valine showed a relatively different response to ammonia concentration. Uptake rate for serine decreased. The rate of increase for arginine (1.5-fold increase at $3.75 \mathrm{mM}$ ) was slow compared to glutamine (1.8-fold increase). On the other hand, the increase in alanine production (2.1-fold) and valine consumption (2.6-fold) was faster.

\section{Antibody Production}

The $\mathrm{IgG}_{1}$ antibody was produced in both the exponential and decline phase of growth (Fig. 2C). About $50 \mathrm{mg} / \mathrm{L}$ antibody was obtained at the end of the culture that had no added ammonia. The antibody concentration was influenced by added ammonia concentration.

The influence of ammonia on antibody concentration was not due to a change in the specific antibody production rate. The specific antibody production rates were evaluated using an integral method described earlier. ${ }^{17,20}$ Figure 2D shows the antibody concentrations plotted against the time integral of viable cells. The experimental data falls on a straight line for all initial ammonia concentrations. The specific antibody production rate 

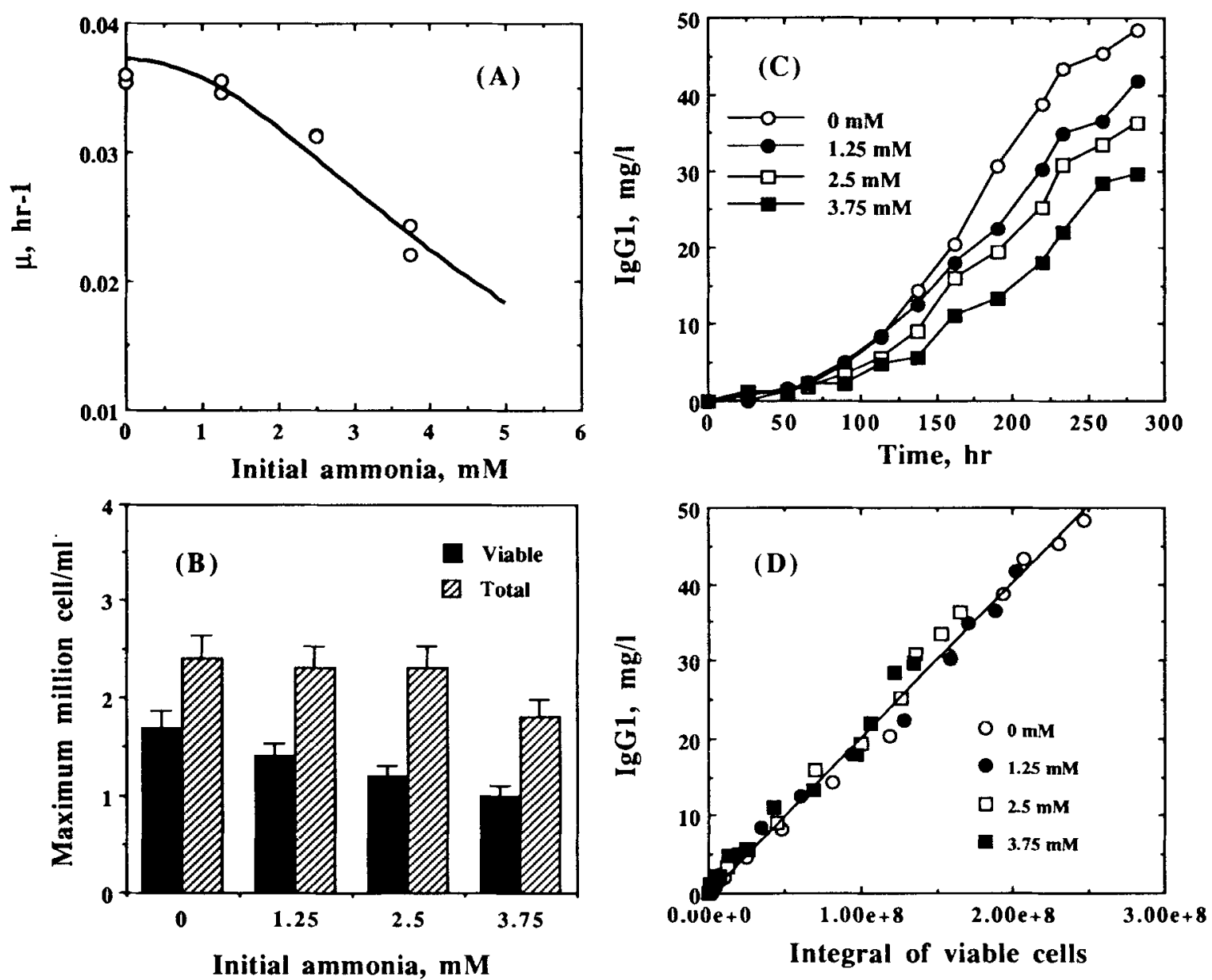

Figure 2. Effect of ammonia on cell growth and IgG production. (A) The influence of specific growth rate by ammonia. The inhibition in specific growth rate was simulated by a second-order inhibition term (solid line) as explained in the text. (B) Maximum viable and total cell concentrations at different levels of initial ammonia. (C) Monoclonal antibody production profiles in batch cultures containing different ammonia. (D) Evaluation of monoclonal antibody productivity using integral method.

was independent of ammonia concentration at a rate of $0.22 \mathrm{pg} / \mathrm{cell} \mathrm{h}$.

\section{Energy Metabolism}

Oxygen uptake rates were insensitive to added ammonia concentrations and remained about $0.10 \mu \mathrm{mol} / 10^{6}$ cell $\mathrm{h}$ (Table V). Together with the lactate production rates, these oxygen uptake rates were used for the estimation of ATP production rates. The ATP production rate increased from $1.12 \mu \mathrm{mol} / 10^{6}$ cell $\mathrm{h}$ at zero ammonia continually by $25 \%$ at $3.75 \mathrm{~m} M$ ammonia (Table V). Table $\mathrm{V}$ also presents the relative contribution of glycolysis and oxidative phosphorylation on ATP production. At $0 \mathrm{~m} M$ ammonia, the oxidative phosphorylation contributed about $60 \%$ of ATP production. However,

Table III. Specific metabolic rates at different ammonia and lactate concentrations.

\begin{tabular}{lccccccc}
\hline $\begin{array}{l}\mathrm{NH}_{4}{ }^{+} \\
(\mathrm{m} M)\end{array}$ & $\begin{array}{c}\text { Lactate } \\
(\mathrm{m} M)\end{array}$ & $\begin{array}{c}\text { Glucose } \\
\text { utilization } \\
\text { rate }\end{array}$ & $\begin{array}{c}\text { Lactate } \\
\text { production } \\
\text { rate }\end{array}$ & $\begin{array}{c}\text { Glutamine } \\
\text { utilization } \\
\text { rate }\end{array}$ & $\begin{array}{c}\text { Ammonia } \\
\text { production } \\
\text { rate }\end{array}$ & $\begin{array}{c}Y_{\text {Lac/Glu }} \\
(\mathrm{mol} / \mathrm{mol})\end{array}$ & $\begin{array}{c}Y_{\mathrm{NH}_{4}+\text { Gin }} \\
(\mathrm{mol} / \mathrm{mol})\end{array}$ \\
\hline $\mathbf{0}$ & 0 & 0.27 & 0.45 & 0.048 & 0.031 & 1.67 & 0.65 \\
1.25 & 0 & 0.31 & 0.49 & 0.058 & 0.036 & 1.58 & 0.62 \\
2.5 & 0 & 0.35 & 0.55 & 0.070 & 0.041 & 1.57 & 0.58 \\
3.75 & 0 & 0.44 & 0.66 & 0.089 & 0.049 & 1.50 & 0.55 \\
0 & 0 & 0.26 & 0.45 & 0.046 & 0.029 & 1.73 & 0.62 \\
0 & 23 & 0.29 & 0.46 & 0.051 & 0.032 & 1.59 & 0.62 \\
0 & 46 & 0.34 & 0.49 & 0.055 & 0.031 & 1.44 & 0.56 \\
0 & 69 & 0.38 & 0.53 & 0.077 & 0.042 & 1.39 & 0.54 \\
\hline
\end{tabular}

The rates are in $\mu \mathrm{mol} / 10^{6}$ cell $\mathrm{h}$ and average of duplicate experiments. 
Table IV. Amino acid consumption and production (in parentheses) rates as a function of the initial ammonia concentrations.

\begin{tabular}{lcccc}
\hline Amino acid & $0 \mathrm{mM}$ & $1.25 \mathrm{mM}$ & $2.5 \mathrm{~m} M$ & $3.75 \mathrm{~m} M$ \\
\hline Aspartate & 1.74 & 2.21 & 2.58 & 3.75 \\
Glutamate & $(2.92)$ & $(1.69)$ & $(2.03)$ & $(3.25)$ \\
Asparagine & 2.13 & 2.26 & 2.67 & 4.18 \\
Serine & $(2.45)$ & $(2.07)$ & $(2.03)$ & $(0.47)$ \\
Glutamine & 48.50 & 58.00 & 67.50 & 89.00 \\
Histidine & 0.12 & 0.23 & 0.35 & 0.20 \\
Glycine & $(0.58)$ & $(0.32)$ & $(0.66)$ & $(0.66)$ \\
Threonine & 3.10 & 3.01 & 3.86 & 4.14 \\
Arginine & 3.18 & 3.24 & 3.61 & 4.89 \\
Alanine & $(34.92)$ & $(42.78)$ & $(55.33)$ & $(72.14)$ \\
Tyrosine & 3.75 & 4.51 & 5.08 & 6.84 \\
Methionine & 2.14 & 2.98 & 2.54 & 3.51 \\
Valine & 5.68 & 8.46 & 9.61 & 14.70 \\
Phenylalanine & 2.21 & 3.48 & 3.86 & 4.57 \\
Isoleucine & 7.06 & 10.84 & 11.26 & 14.16 \\
Leucine & 8.64 & 11.14 & 13.35 & 18.57 \\
Lysine & 5.39 & 6.94 & 8.17 & 11.73 \\
\hline
\end{tabular}

The rates are in $\mathrm{nmol} / 10^{6}$ cell $\mathrm{h}$.

this percentage decreased at high ammonia concentrations, and at $3.75 \mathrm{mM}$ ammonia, the contribution was about $50 \%$.

\section{Intracellular $\mathrm{pH}$}

Intracellular $\mathrm{pH}$ measurements were measured in a transient mode when cells were suspended in a $\mathrm{pH}$ buffer at 7.2 and then exposed to various ammonia concentrations. Initially the intracellular $\mathrm{pH}$ rose but then decreased to values lower than initial values (Fig. 3A). Intracellular $\mathrm{pH}$ values were stabilized after about $30-$ $40 \mathrm{~min}$. The steady-state values reported in Table VI were dependent on the ammonia concentration.

\section{Effects of Lactate}

Experimental data describing cell growth and metabolism in the presence of various initial lactate concentrations is summarized in Figure 4. Cell growth was suppressed by lactate (Fig. 4A). The growth rate in the culture with a $69 \mathrm{mM}$ initial lactate concentration was very low. Glucose consumption and lactate pro- duction continued in all the cultures until cell growth declined (Fig. 4B). Glutamine again was the limiting nutrient for growth, as evident from the coinciding cessation of growth and glutamine depletion for all the cultures, except the $69 \mathrm{~m} M$ lactate batch (Fig. 4C). Antibody concentration profiles were similar in the cultures with $0 \mathrm{~m} M, 23 \mathrm{~m} M$, and $46 \mathrm{~m} M$ initial lactate concentrations.

\section{Cell Growth}

Specific growth rates were calculated for the exponential phase and are presented in Figure 5. The growth rates decreased at higher initial lactate concentrations. Lactate inhibition of growth was similar to that of ammonia; however, the concentration of lactate needed to reach a particular growth inhibition was about 10 times higher than the corresponding ammonia concentration.

The effect of lactate on cell growth was partially due to the changes in media osmolarity. The measured osmolarities for media containing 23,46 , and $69 \mathrm{mM}$ initial lactate were 330,370 , and 420 , respectively. We have reported decreased growth rates at elevated osmolarities. ${ }^{19}$ In our previous study on osmolarity, the media osmolarity was increased by three different solutes: $\mathrm{NaCl}, \mathrm{PBS}$ salts, and sucrose. ${ }^{19}$ The effect of increased osmolarity on cell growth, metabolic, and specific antibody production rates was essentially identical for all three solutes. These results can thus be used to distinguish between the direct chemical action of lactate and the effects it has through raising the osmolarity of the medium. We can use the results from our earlier study ${ }^{19}$ as a "baseline" that corresponds to the effects of osmolarity. Deviations from this baseline are then attributed to the chemical action of lactate. The corrected cell growth rates are presented in Figure 5A. Based on this line of reasoning, the direct chemical action of lactate becomes pronounced at concentrations above 40-50 $\mathrm{m} M$.

The death rates evaluated are presented in Figure 5B. The death rates were higher at high lactate concentration, and this effect was due primarily to the effect of elevated medium osmolarity. At high osmolarities we have observed a similar increase in death rates. ${ }^{19}$

Table V. Effect of ammonia and lactate on the oxygen consumption and ATP production rate.

\begin{tabular}{|c|c|c|c|c|c|c|}
\hline $\begin{array}{l}\mathrm{NH}_{4}{ }^{+} \\
(\mathrm{m} M)\end{array}$ & $\begin{array}{l}\text { Lactate } \\
(\mathrm{m} M)\end{array}$ & $\begin{array}{c}\text { Oxygen } \\
\text { consumption } \\
\text { rate }\end{array}$ & $\begin{array}{c}\text { Lactate } \\
\text { production } \\
\text { rate }\end{array}$ & $\begin{array}{l}\text { ATP } \\
\text { production } \\
\text { rate }\end{array}$ & $\begin{array}{l}\text { Oxidative } \\
\text { phosphorylation } \\
\text { contribution (\%) }\end{array}$ & $\begin{array}{c}\text { Glycolytic } \\
\text { contribution }(\%)\end{array}$ \\
\hline 0 & 0 & 0.112 & 0.45 & 1.12 & 60 & 40 \\
\hline 1.25 & 0 & 0.106 & 0.49 & 1.13 & 57 & 43 \\
\hline 2.5 & 0 & 0.102 & 0.55 & 1.16 & 53 & 47 \\
\hline 3.75 & 0 & 0.109 & 0.66 & 1.31 & 50 & 50 \\
\hline 0 & 0 & 0.108 & 0.45 & 1.09 & 59 & 41 \\
\hline 0 & 23 & 0.102 & 0.46 & 1.08 & 57 & 43 \\
\hline 0 & 46 & 0.108 & 0.49 & 1.13 & 57 & 43 \\
\hline 0 & 69 & 0.110 & 0.53 & 1.19 & 56 & 44 \\
\hline
\end{tabular}

The rates are in $\mu \mathrm{mol} / 10^{6}$ cell $\mathrm{h}$. Glycolytic contribution to energy production is calculated from lactate production. 

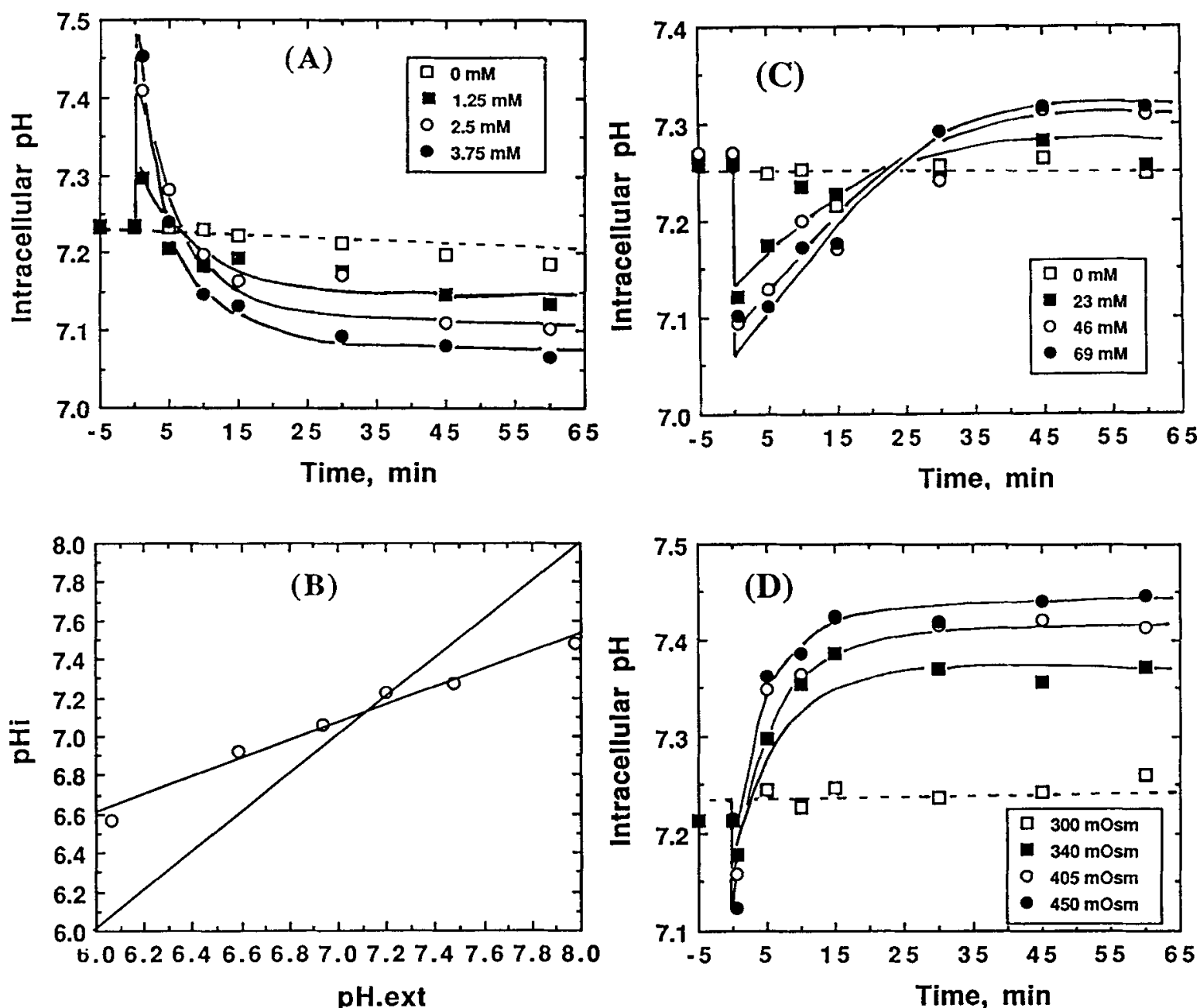

Figure 3. Results from intracellular pH measurements. (A) Effects of ammonia addition on intracellular $\mathrm{pH}$. (B) Effect of external pH. (C) Effects of lactate addition. (D) Effects of osmolarity. Cells are suspended in $\mathrm{pH} 7.2$ buffer and at time zero ammonia, lactate, or medium at higher osmolarity was added. The internal $\mathrm{pH}$ values were obtained from fluorescence measurements using a calibration curve similar to that described in ref. 13.

Table VI. Effect of ammonia, lactate, and osmolarity on intracellular $\mathrm{pH}$ at external $\mathrm{pH}$ of 7.20 .

\begin{tabular}{lccccc}
\hline $\begin{array}{c}{\left[\mathrm{NH}_{4}{ }^{+}\right]} \\
(\mathrm{m} M)\end{array}$ & $\begin{array}{c}\text { Lactate } \\
(\mathrm{m} M)\end{array}$ & $\begin{array}{c}\text { Osmolarity } \\
(\mathrm{mOsm})\end{array}$ & $\begin{array}{c}\text { Peak } \\
\mathrm{pH}_{i}\end{array}$ & $\begin{array}{c}\text { Steady-state } \\
\mathrm{pH}_{i}\end{array}$ & $\Delta \mathrm{pH}$ \\
\hline 0 & 0 & 300 & 7.23 & 7.20 & 0 \\
1.25 & 0 & 300 & 7.30 & 7.14 & -0.06 \\
2.5 & 0 & 300 & 7.42 & 7.10 & -0.10 \\
3.75 & 0 & 300 & 7.43 & 7.07 & -0.13 \\
0 & 0 & 300 & 7.25 & 7.25 & 0 \\
0 & 23 & 300 & 7.13 & 7.29 & 0.1 \\
0 & 46 & 300 & 7.10 & 7.31 & 0.12 \\
0 & 69 & 300 & 7.06 & 7.32 & 0.13 \\
0 & 0 & 300 & 7.23 & 7.23 & 0 \\
0 & 0 & 340 & 7.17 & 7.37 & 0.14 \\
0 & 0 & 405 & 7.15 & 7.41 & 0.18 \\
0 & 0 & 430 & 7.12 & 7.44 & 0.21
\end{tabular}

The $\Delta \mathrm{pH}$ shows the change in the internal $\mathrm{pH}$ due to the addition of ammonia, lactate, and osmolarity additions. Three experiments were performed separately for the effects of ammonia, lactate, and osmolarity.

\section{Cell Metabolism}

Glucose and glutamine uptake rates are shown in Figure $5 \mathrm{C}$. These rates were found to increase with lactate concentration. Similar increases were observed for the production rates of ammonia and lactate (Table III). The increase in these metabolic rates was consistent with the changes due to increased osmolarity. ${ }^{19}$ When the rates were corrected for the effects of osmolarity by the procedure outlined above, we obtained an actual decrease in these rates (Fig. 5).

The yield coefficients calculated from both experimental and the osmolarity-corrected metabolic rates were the same. The lactate yield coefficient from glucose and ammonia yield from glutamine decreased by increasing lactate concentration (Table III).

\section{Antibody Production}

The specific antibody production rates were evaluated by an integral method. ${ }^{17-20}$ For each batch, we obtained 

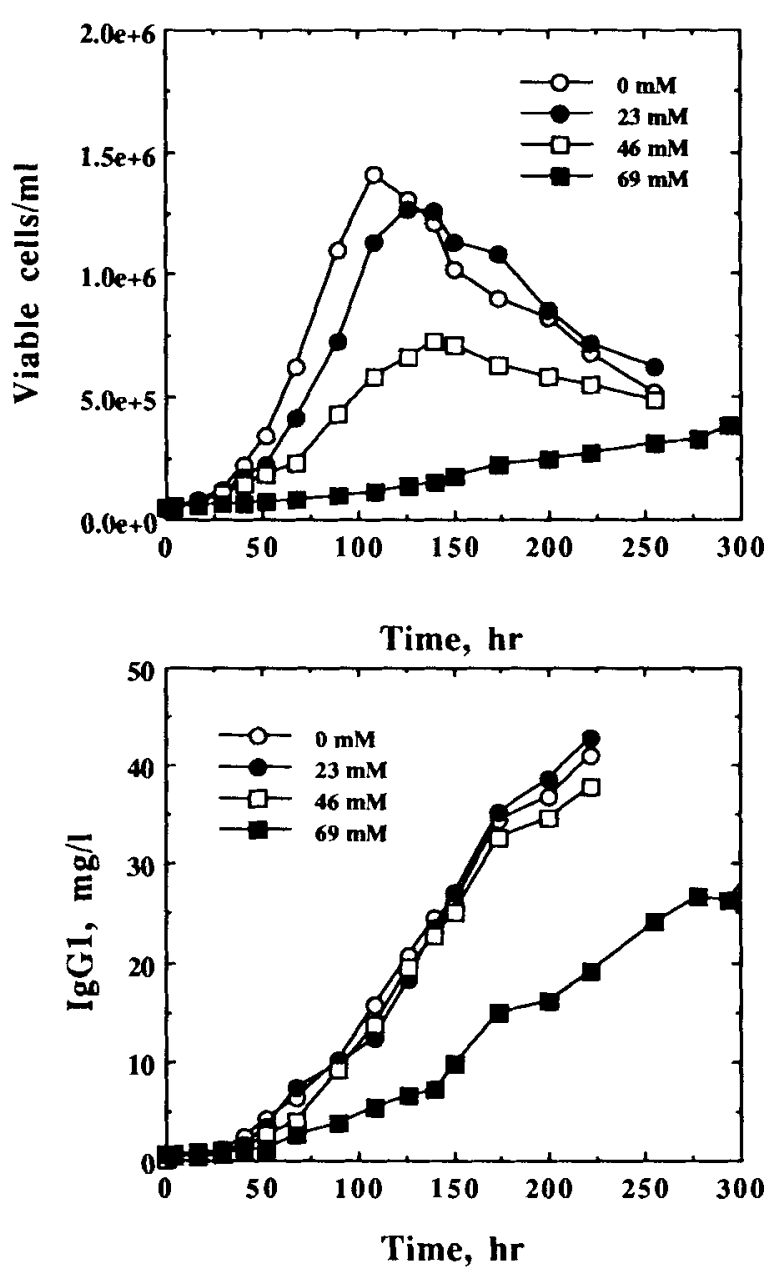

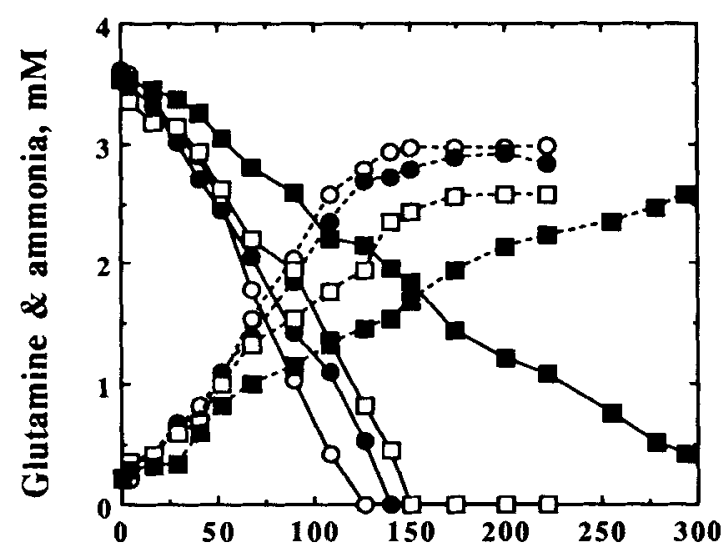

Time, hr

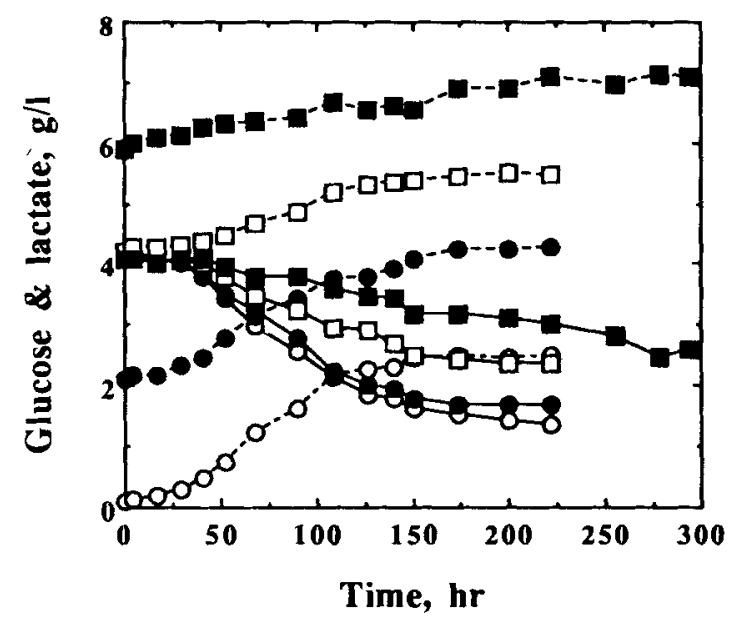

Figure 4. Effect of lactate on cell growth, metabolism, and antibody production: (A) viable cell concentrations; (B) antibody concentrations; (C) glutamine and ammonia concentrations; and (D) glucose and lactate concentrations.

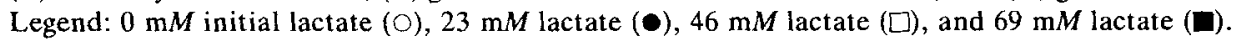

a straight line for the plot of antibody concentration vs. the time integral of viable cells (Fig. 6A). The slopes, and hence the specific antibody production rates, were different. The rates are summarized in Figure $6 \mathrm{~B}$ as a function of initial lactate concentration. Elevated lactate concentrations increased the specific antibody production rate, mainly due to the influence of osmolarity. When the rates were corrected by considering the effects of osmolarity, a relatively constant specific production rate was obtained.

\section{Energy Metabolism}

The measured oxygen uptake rates are presented in Table V. There was no influence of added lactate on the specific oxygen uptake rate. The ATP production rates are also presented in Table V. Added lactate resulted in a slight increase in ATP production rate by $10 \%$. The relative contribution of oxidative phosphorylation decreased from $60 \%$ at zero lactate and decreased to $56 \%$ at $69 \mathrm{~m} M$ lactate.

\section{Intracellular $\mathrm{pH}$}

Cells suspended at $\mathrm{pH} 7.2$ were exposed to different lactate concentrations, and intracellular $\mathrm{pH}$ values were monitored (Fig. 3C). There was an initial decrease in intracellular $\mathrm{pH}$ followed by an increase. The final intracellular $\mathrm{pH}$ values were slightly higher than the initial values. These measurements are summarized in Table VI.

\section{DISCUSSION}

\section{Effects of Ammonia}

\section{Cell Growth}

Cell growth was inhibited by ammonia and an ammonia concentration of $4 \mathrm{~m} M$ decreased the specific growth rate by $50 \%$. This ammonia concentration was compared in Table 1 with the other studies. The different values for the ammonia concentration needed to decrease the growth rate by $50 \%$ indicate that hybridoma 


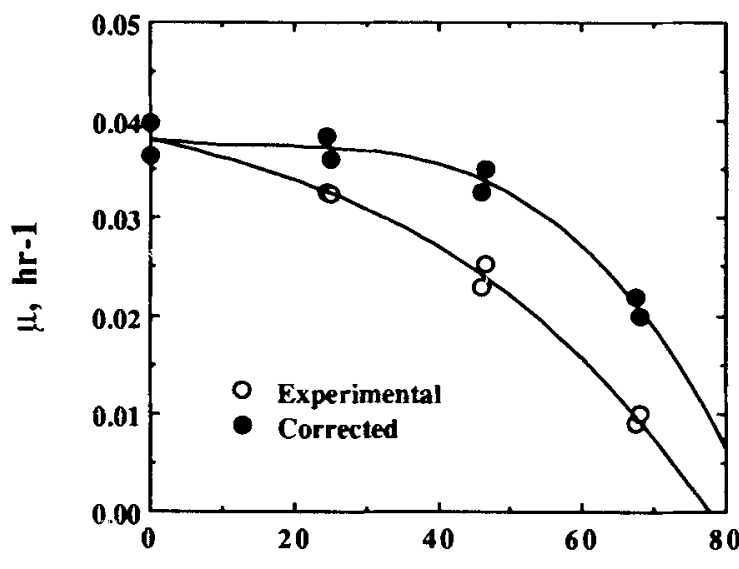

Initial Lactate, $\mathrm{mM}$

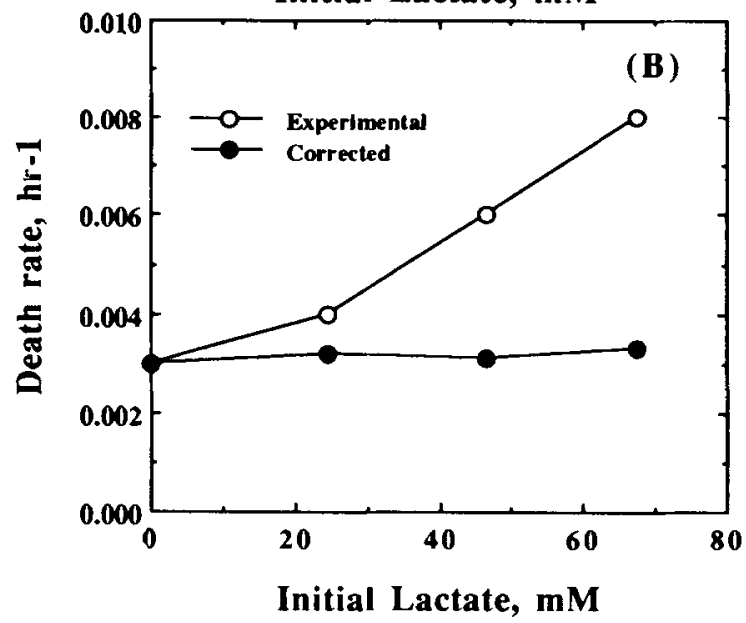

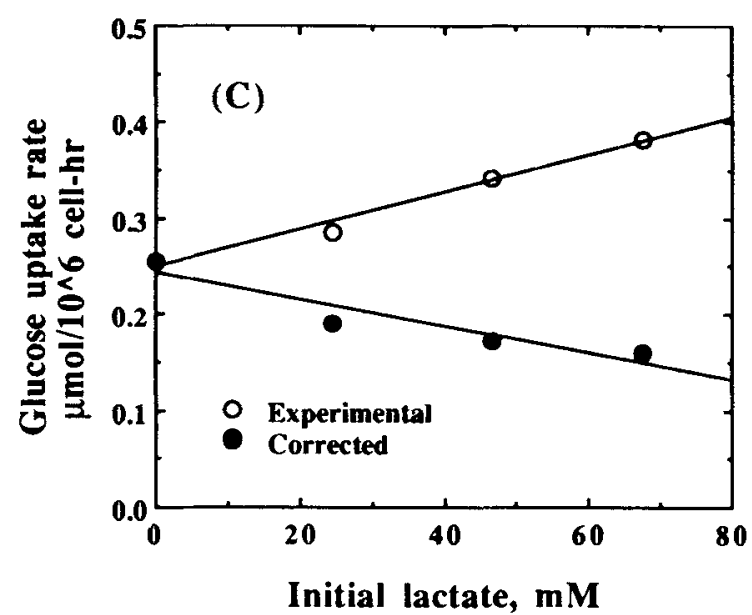

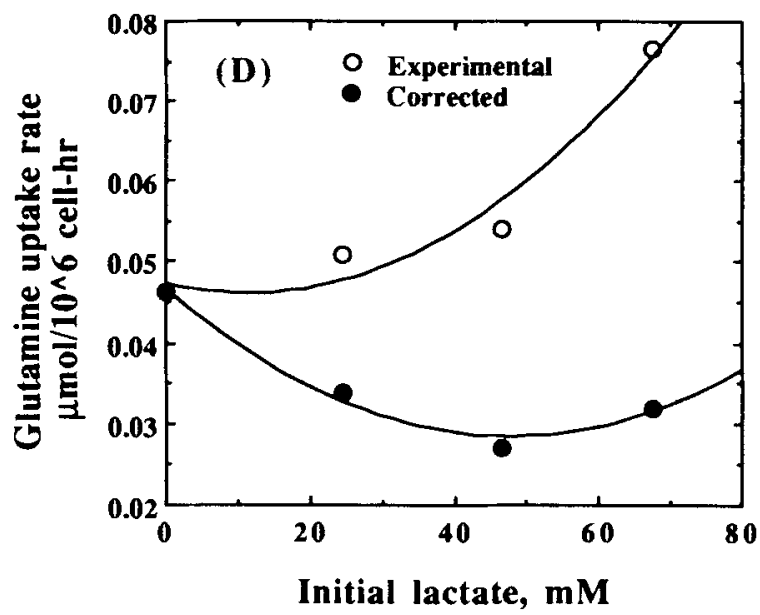

Figure 5. Effect of added lactate on (A) cell growth rate, (B) death rate, (C) glucose, and (D) glutamine uptake. Experimental data (open symbols) was corrected for the effect of osmolarity (closed symbols).

cell lines vary somewhat in their sensitivity to ammonia inhibition. Glacken et al. reported ammonia inhibition of growth for a murine hybridoma cell line (CRL-1606) at $5 \mathrm{mM}{ }^{4}$ For another hybridoma cell line, Reuveny et al. showed that $3 \mathrm{~m} M$ ammonia inhibited the cell growth by $50 \% .^{3}$ Truskey et al. observed growth inhibition at $2 \mathrm{~m} M$ ammonia for hybridoma cells (SB-4082) grown in a fed-batch reactor. ${ }^{23}$ In general, hybridoma cells appear to be more tolerant to ammonia than other mammalian cells. For instance, inhibition of cell growth for 3T3 cells was observed below $1 \mathrm{~m} M$ ammonia. ${ }^{25}$ When the $3 T 3$ cells were transformed by SV-40, the extent of inhibition decreased. Ammonia inhibition of mouse $\mathrm{L}$ cells was observed at concentrations below $1 \mathrm{~m} M$ ammonia. ${ }^{16}$ Similar inhibitory ammonia concentrations have been reported for BHK cells. ${ }^{3}$ The specific rates were fitted successfully by an inhibition model with an inhibition constant of $24 \mathrm{~m} M^{2}$. For comparison, we note that a $K_{a}$ value of $26 \mathrm{~m} M^{2}$ was reported for the CRL-1606 hybridoma cell line, ${ }^{5}$ but the value reported for the SB-4082 hybridoma cell line was almost one order of magnitude lower $\left(K_{a}=3.2 \mathrm{mM}^{2}\right){ }^{23}$

The death rates were observed to be independent of ammonia concentrations. This result implies that the action of ammonia is not directly on cell death. McQueen and Bailey suggested that ammonia acts to reduce the cell yield from late-limiting nutrient. ${ }^{9}$ Trusky et al. observed that ammonia caused a decrease in the death rate of a $\mathrm{T}$ cell lymphoma. ${ }^{23}$ Elevated ammonia concentrations did not influence the cell viability significantly. Larger numbers of cells were produced at low ammonia concentrations simply because of higher cell specific growth rates.

\section{Cell Metabolism}

Metabolic rates for glucose, glutamine, lactate, ammonia, and most amino acids increased about twofold in the presence of $3.75 \mathrm{mM}$ ammonia. The increases in glucose and glutamine consumption with increased ammonia concentrations are consistent with the data of Miller et al. obtained for AB2-143.2 hybridoma cell line. ${ }^{12}$ However, this increase was reported to diminish at ammonia concentrations above $5 \mathrm{mM} \cdot{ }^{12}$ Glacken et al. have also shown an increase in glutamine uptake rate by added ammonia, which is in agreement with our data. Increases in metabolic activity at elevated ammonia concentrations for other mammalian cells have also been reported. ${ }^{1}$ McQueen and Bailey indicated an increase in hybridoma cell yield on glucose and glutamine. ${ }^{9}$ Our 

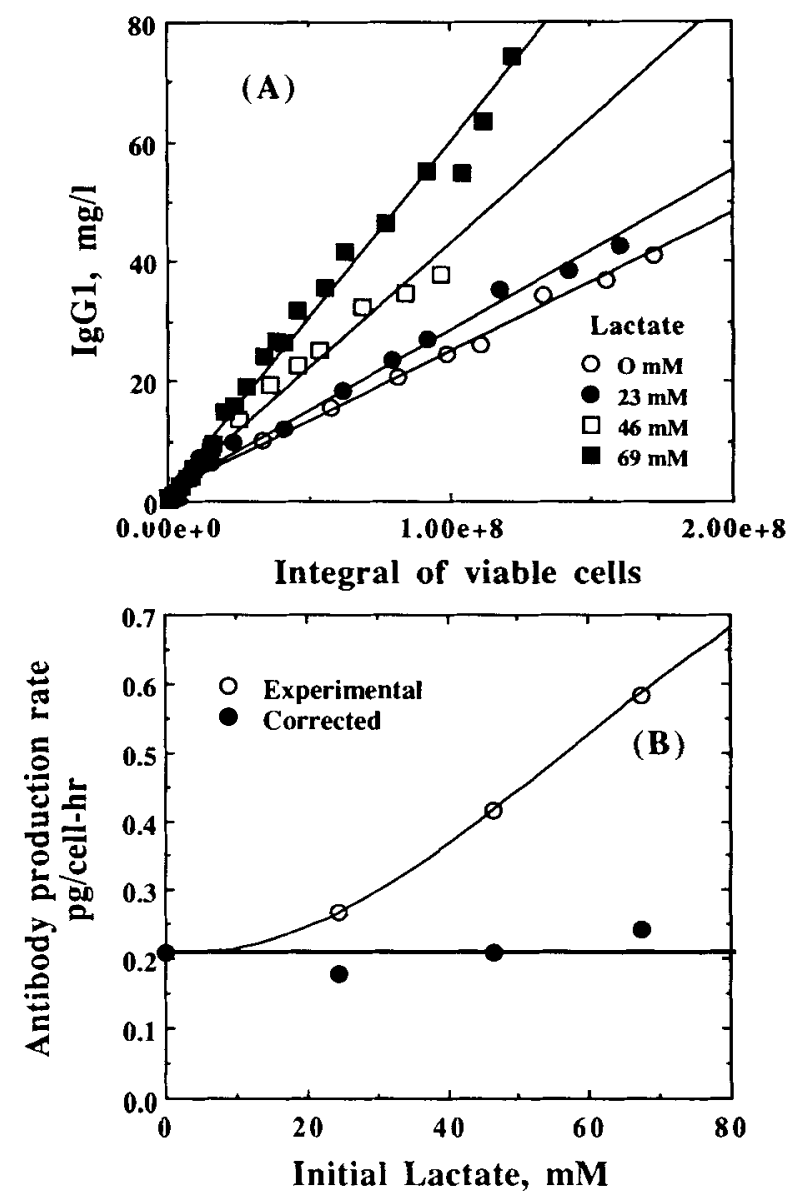

Figure 6. (A) Evaluation of monoclonal antibody productivity using integral method. (B) Monoclonal antibody production rate as a function of lactate concentrations. Addition of lactate increased by cell specific antibody production rate by a factor of 3 . This was probably due to the alteration of medium osmolarity.

results show a decrease in growth rate and an increase in metabolic rate leading to an increase in cell yields. However, it is not clear from McQueen and Bailey's data whether the increased cell yields resulted from a decrease in growth rate or an increase in metabolic rate.

The yield coefficient of lactate from glucose and the yield coefficient of ammonia from glutamine decreased, while alanine yield from glutamine increase as a result of ammonia addition. Miller et al. observed similar data for ammonia yield from glutamine. ${ }^{12}$ A decrease in the lactate yield coefficient has been reported at elevated ammonia concentrations for other mammalian cells. ${ }^{1}$ Similarly, McQueen and Bailey reported a decrease in lactate yield from glucose and in ammonia yield from glutamine. ${ }^{9}$ We have seen an increase in ammonia yield from glutamine at elevated ammonia yields. We have observed an acceleration in amino acid metabolism. Such increase in amino acid metabolic rates was observed for the $\mathrm{C} 127$ cell line. ${ }^{1}$ Ammonia yields on glutamine were calculated from alanine production rate $\left(q_{\mathrm{Ala}}\right)$ and glutamine consumption rate $\left(q_{\mathrm{Gln}}\right)$ as $Y_{\mathrm{Ala} / \mathrm{Gln}}=q_{\mathrm{Ala}} / q_{\mathrm{Gln}}$ using data in Table IV. Alanine yield on glutamine increased from 0.72 to $0.82 \mathrm{~mol} / \mathrm{mol}$ as ammonia concentration increased from 0 to $3.75 \mathrm{mM}$. Such an increase was reported by Miller et al. ${ }^{12}$ An increase in amino acid metabolic rates was observed for the $\mathrm{C} 127$ cell line. ${ }^{1}$

\section{Antibody Production}

The amount of antibody produced was lower at high ammonia concentrations. This resulted because of differences in cell concentrations. This result is consistent with the results of Reuveny et al. ${ }^{15}$ We have shown that the cell specific antibody productivity was not influenced by ammonia concentration. Glacken et al. reported a decrease in antibody productivity at elevated ammonia levels. ${ }^{5}$ However, these productivities were based on total cell counts. It may well be that cell viability at high ammonia levels was low, leading to lower viable cell concentrations and higher or similar antibody productivities. Our results also are in agreement with the data of McQueen and Bailey, who reported relatively constant specific antibody productivities. ${ }^{9}$

\section{Energy Metabolism}

Cell specific oxygen uptake rate was insensitive to ammonia concentrations. Miller et al. observed a decrease in oxygen uptake at high ammonia concentrations in a continuous reactor operation. ${ }^{12}$ Differences in cell line and reactor operation are probable reasons for this difference. On the other hand, our results are in agreement with the data of Kimura et al. for a human leukemia cell ${ }^{7}$; they observed no influence of ammonia on cell specific oxygen consumption rate. The ATP production rate increased with the ammonia addition. This increased energy production is not, however, used for growth as the growth rate was inhibited. It appears that the cells produce more energy under stressful conditions and use it for maintenance. The relative contribution of oxidative phosphorylation decreased and the contribution of glycolysis increased with elevated ammonia. This result is in agreement with the data of Miller et al. ${ }^{12}$

\section{Intracellular $\mathrm{pH}$}

A possible mechanism for ammonia alteration of cell growth and metabolism is simply through changes in intracellular $\mathrm{pH}$. The regulation of intracellular $\mathrm{pH}$ in response to added ammonia is complex. Free ammonia and ammonium ion are present at equilibrium at a ratio determined by medium $\mathrm{pH}$. At the $\mathrm{pH}$ values used in our experiments, almost all the ammonia present is in the form of ammonium ion and concentration of dissolved ammonia gas is very low $\left(\mathrm{p} K_{a}=9.2\right)$. The permeability of dissolved ammonia gas is much greater than that of the ammonium ion. ${ }^{6,11}$ Thus, initially ammonia gas rapidly permeates, raising the intracellular $\mathrm{pH}$. Then the slower penetration of ammonium ion decreases the $\mathrm{pH}$.

Our experimental observations presented in Figure 3 are consistent with the above mechanism. Our data 
show an immediate increase in intracellular $\mathrm{pH}$ followed by a decay to steady-state intracellular $\mathrm{pH}$ values that are lower than those observed prior to the exposure to ammonia. Compared to the control flask with no ammonia addition (control), a decrease of $\Delta \mathrm{pH}=0.13$ in the steady-state intracellular $\mathrm{pH}$ value was observed at $3.75 \mathrm{mM}$ ammonia. This decrease was on the same order of magnitude as the data reported by McQueen and Bailey. ${ }^{10}$

A change in intracellular $\mathrm{pH}$ can alter the activity of numerous metabolic enzymes. The rise in intracellular $\mathrm{pH}$ by the uptake of ammonia gas into the lysosomes has been demonstrated in the literature. ${ }^{14,24}$ On the other hand, McQueen and Bailey have shown that the net result of ammonia addition is a decrease in intracellular $\mathrm{pH}$ for hybridoma cell line ATCC TIB $131^{10,11}$ Based on the measurements of internal $\mathrm{pH}$, McQueen and Bailey could relate the effects of ammonia addition to the effects of low external $\mathrm{pH}$ as they both led to cytoplasmic acidification.

The effects of extracellular $\mathrm{pH}$ on intracellular $\mathrm{pH}$ for the hybridoma cell line $167.4 \mathrm{G5} .3$ is presented in Figure $3 \mathrm{~B}$. It is clear that we have a direct correlation between the extracellular and intracellular $\mathrm{pH}$. Our data for the same cell line under controlled $\mathrm{pH}$ conditions led to a decrease in glucose uptake and an increase in glutamine uptake rates when $\mathrm{pH}$ was below $7.2 .{ }^{18} \mathrm{~A}$ decrease in intracellular $\mathrm{pH}$ as a result of ammonia addition, however, increased both rates. ${ }^{*}$ McQueen and Bailey observed that both ammonia addition and low external $\mathrm{pH}$ resulted in lower cell yields on glucose and glutamine and concluded that they are related in their inhibitory action, i.e., reducing the internal $\mathrm{pH} .{ }^{10}$ Note that cell yields on metabolites reported by McQueen and Bailey are combined parameters (growth rate and cell specific consumption rates).

Our individually evaluated kinetic parameters indicate that for the cell line used in this study, we could not relate the effects of ammonia addition to the effects of lowering external $\mathrm{pH}$. Miller et al. observed an increase in glucose uptake rate as a result of ammonia addition, although the decrease in extracellular $\mathrm{pH}$ led to a decrease, in good agreement with our data. ${ }^{12}$ The intracellular $\mathrm{pH}$ at $3.75 \mathrm{~m} M$ ammonia was 7.07 . This intracellular $\mathrm{pH}$ could be obtained at an extracellular $\mathrm{pH}$ of 7.0. The growth rate obtained at $3.75 \mathrm{mM}$ ammonia $\left(\mu=0.022 \mathrm{~h}^{-1}\right)$ was lower than the growth rate at pH $7.0\left(\mu=0.032 \mathrm{~h}^{-1}\right)$. The glutamine uptake rates for $3.75 \mathrm{~m} M$ ammonia $\left(q_{\mathrm{Gln}}=0.070 \mu \mathrm{mol} / 10^{6}\right.$ cell h) and $\mathrm{pH} 7.0\left(q_{\mathrm{Gln}}=0.055 \mu \mathrm{mol} / 10^{6}\right.$ cell $\left.\mathrm{h}\right)$ were also different. These data suggest that cytoplasmic acidifica-

Although experiments presented here have not been carried out under controlled $\mathrm{pH}$ conditions, the $\mathrm{pH}$ was relatively constant around 7.2 in the exponential phase due to the high buffering capacity of the medium. The specific growth, metabolic, and antibody production rates evaluated at zero ammonia concentration were very close to the values obtained in a controlled bioreactor at pH 7.2 under similar operating conditions. tion, due to either ammonia addition or lowering the extracellular $\mathrm{pH}$, may be acting in a different manner. The attribution of the effects of ammonia to cytoplasmic acidification failed to explain the increase in glucose uptake rate as the cell specific uptake rate of glucose decreased at low $\mathrm{pH}$ values. ${ }^{18}$ The ATP production was also influenced differently from ammonia addition (increasing rate) and from lowering external $\mathrm{pH}$ (decreasing rate) for the cell line considered here.

\section{Effect of Lactate}

\section{Cell Growth}

Cell growth rates decreased at high lactate concentrations. However, as compared to ammonia, the inhibition of cell growth by lactate occurred at relatively high concentrations (i.e., $55 \mathrm{mM}$ ). A similar inhibition by lactate on growth of the CRL-1606 cell line was observed. ${ }^{5}$ Miller et al. did not observe an inhibition for cell growth at $40 \mathrm{~m} M$ lactate. ${ }^{12}$ Thorpe et al. also did not observe any inhibition at $10 \mathrm{~m} M$ lactate. 22 Apparently lactate inhibition needs higher concentrations than covered by these studies. Reuveny et al., on the other hand, reported a stimulation of cell growth for lactate concentrations up to $22 \mathrm{mM}$. The inhibitory effects of lactate were then observed. ${ }^{15}$ Our data shows that specific death rates increase with increased lactate concentration. However, this increase can be attributed to increased osmolarity. Similarly, ammonia did not influence the death rate.

\section{Cell Metabolism}

Metabolic rates for glucose, glutamine, lactate, and ammonia increased as a result of lactate addition. By comparing the inhibition of growth by lactate to that obtained in medium of identical osmolarity, we are able to separate the chemical action of lactate from that due to osmolarity. Only at very high lactate levels $(>40 \mathrm{mM}$ ) do we obtain a significant difference between lactatecontaining cultures as compared to those of the same osmolarity. Only Miller et al. reported the cell specific activities as a function of lactate. ${ }^{12}$ Altering lactate concentration from 25 to $44 \mathrm{~m} M$ did not change the specific rates of glucose and glutamine, and there was little decrease in the ammonia and lactate production rates. ${ }^{2}$ The net result is a decreased yield coefficient of lactate from glucose and of ammonia from glutamine. We have observed similar decreases in these yield coefficients. Our results are in good agreement with the data of Miller et al.

\section{Antibody Production}

Although the amount of antibody accumulated in the batch mode was lower at high lactate concentrations, 
we obtained increased cell specific antibody production rates under these conditions. This increase in antibody production is identical to the corresponding increase due to increase in osmolarity. ${ }^{5}$ When the specific antibody productivities are compared under the same osmolarity conditions, the chemical effect of lactate on cell specific antibody production was negligible. Glacken et al. observed a decrease in specific antibody production rate under controlled osmolarity conditions. ${ }^{5}$ However, his data were based on the total cell numbers. It is possible that the viable cell numbers at high lactate concentrations were less. The specific antibody productivities could have been constant if the viable cell concentrations had been used in their calculations.

\section{Energy Metabolism}

The oxygen consumption rate was observed to be insensitive to lactate concentration. Miller et al. reported similar data in a continuous culture. ${ }^{12}$ Kimura et al. studied the influence of lactate on the oxygen uptake rate of a human leukemia cell line. ${ }^{7}$ Our results are then in agreement with these studies. Estimated energy production increased as the lactate concentration increased. The ATP production rate was elevated by $16 \%$ at $69 \mathrm{mM}$ lactate addition. As in the case of ammonia, it seems that cells acquire more energy when the growth is inhibited. The contribution of glycolysis into the energy production increased at high lactate concentrations. We have observed similar effects of ammonia on the distribution of energy sources.

\section{Intracellular $\mathrm{pH}$}

As for ammonia, the effects of lactate may be mediated through the alteration of intracellular $\mathrm{pH}$. We have seen only a marginal increase in intracellular $\mathrm{pH}$ at elevated lactate concentrations. Then the effects of lactate on cell metabolism is not due to the alteration of intracellular $\mathrm{pH}$. The effects of lactate observed in this study seem to be related more to the changes in medium osmolarity. We have attempted to separate the chemical effects of lactate and the osmolarity effects by comparing the results under the same osmolarities. Our work on the effects of osmolarity was used for "correcting" the cell specific rates. ${ }^{19}$ Under these conditions, we have shown that the increase in cell specific death and cell specific antibody production rates were mainly due to osmolarity. We have also attempted to use the osmolarity data to correct the metabolic rates. This correction procedure, however, assumes that the chemical action of lactate and the osmolarity effects are not interrelated. However, we could not test this assumption in the present framework. Nonetheless, we have compared the effects of osmolarity and lactate on intracellular $\mathrm{pH}$. Figure 3D summarizes the response of intracellular $\mathrm{pH}$ to increasing osmolarity. We see a cytoplasmic alkalin- ization at higher osmolarities, which was increased by the addition of $\mathrm{NaCl}$ and $\mathrm{KCl}$. The increase in intracellular $\mathrm{pH}$ is most likely due to the action of a $\mathrm{Na}^{+} / \mathrm{H}^{+}$ pump, as demonstrated for other cell lines. ${ }^{13}$ The steadystate values for intracellular $\mathrm{pH}$ were presented in Table VI. The increase in intracellular $\mathrm{pH}$ was very low for the addition of lactate. Under these conditions, the increase in $\mathrm{pH}$ due to the action of the $\mathrm{Na}^{+} / \mathrm{H}^{+}$pump was probably counterbalanced by the diffusion of lactic acid into the cells. Differences in the response of cells to intracellular $\mathrm{pH}$ for osmolarity and lactate indicate the difficulty of separating the chemical effects of lactate from the osmolarity effects. However, the effects of lactate observed in this work could not be attributed to the alteration of intracellular $\mathrm{pH}$ as it was relatively constant. More refined studies under controlled osmolarity conditions are needed to fully understand the chemical action of lactate.

\section{CONCLUSIONS}

Ammonia and lactate are important metabolic byproducts that are known to inhibit hybridoma cell growth. In this study we have analyzed the effects of these metabolites on cell growth, metabolism, and antibody production. Several conclusions can be drawn from the present work.

1. Cell growth rate of the hybridoma cell line $167.4 \mathrm{G} 5.3$ is inhibited by $50 \%$ at $4 \mathrm{mM}$ ammonia. Together with the literature data, this relatively high ammonia concentration indicates that hybridoma cells are more tolerant to ammonia inhibition than primary cell lines. Cell viability and the specific death rate are less sensitive to ammonia levels. Less cells are attained in the batch mode when the ammonia concentration is high.

2. Specific metabolic rates (glucose, glutamine, ammonia, lactate, amino acids) are accelerated at higher ammonia concentrations. Cells are more active metabolically when the growth is suppressed. Decrease in lactate yield from glucose and in ammonia yield from glutamine is accompanied by an increase in alanine yield from glutamine.

3. Specific antibody production rate is not influenced by ammonia concentration. Cultures at higher ammonia levels result in lower antibody levels due to the low cell concentrations obtained.

4. Oxygen uptake rate is insensitive to ammonia levels. Total energy production increases at elevated ammonia concentrations. Glycolysis is preferred when the culture is stressed by ammonia inhibition.

5. Ammonia results in cytoplasmic acidification for the hybridoma cell used. Although the same intracellular $\mathrm{pH}$ could be obtained by lowering the external $\mathrm{pH}$ and increasing the ammonia concentrations, cells behave differently, revealing the chemical effects of ammonia. 
6. The inhibitory concentration of lactate is at least one order of magnitude higher than that for ammonia. Cell specific death rates are higher at high lactate concentrations. This increase is analogous to that observed for the corresponding increase in medium osmolarity.

7. Specific metabolic rates (glucose, glutamine, ammonia, lactate) are accelerated when the cells are stressed at higher lactate concentrations. This increase could be due to the action of increased osmolarity. Lactate yield from glucose and ammonia yield from glutamine decreased at elevated ammonia concentrations.

8. Cell specific antibody productivity increased by a factor of 2 at high lactate concentrations. However, the antibody concentrations obtained did not change because fewer cells are produced. The increase in antibody productivity could be attributed to the alteration of medium osmolarity.

9. Specific oxygen uptake rates were not affected by lactate concentration. Cells obtained more energy at higher lactate concentrations. Glycolytic contribution to total ATP production increased when the cells were stressed at high lactate levels.

10. Intracellular $\mathrm{pH}$ was not altered very much by the presence of higher lactate concentrations. This result was probably due to the counteraction of the $\mathrm{Na}^{+} / \mathrm{H}^{+}$pump and the passage of lactic acid to the cells. The effects of lactate were not related to the changes in intracellular $\mathrm{pH}$.

This work was supported by the National Science Foundation Grant Nos. EET-8712756 and BCS-9009389. The authors thank Dr. J. Latham Claflin for providing the hybridoma cell line used in this study. A part of this work was presented at the 200th National ACS Meeting in Washington, DC, August 29, 1990.

\section{References}

1. Alex, P. C., Barngrover, D., Swartz, R.W. 1989. Development of a small scale model to investigate the rate limiting kinetics of $\mathrm{C} 127$ anchorage-dependent cells during perfusion. Paper presented at ACS National Meeting in Miami, FL.

2. Briles, D. E., Forman, C., Hudak, S., Claflin, J. L. 1984. The effects of idiotype on the ability of IgG $_{1}$ anti-phosphorylcholine antibodies to protect mice from fatal infection with Streptococcus pneumoniae. Eur. J. Immunol. 14: 1027.

3. Butler, M., Spier, R. E. 1984. The effects of glutamine utilization and ammonia production on the growth of BHK cells in microcarrier cultures. J. Biotechnol. 1: 187.

4. Eagle, H. 1973. The effects of environmental $\mathrm{pH}$ on the growth of normal and malignant cells. J. Cell. Physiol. 82: 1.

5. Glacken, M.W. 1987. Development of mathematical descriptions of mammalian cell culture kinetics for the optimization of fed-batch bioreactors. Ph.D. Thesis, Massachusetts Institute of Technology, Cambridge, MA.
6. Glacken, M.W. 1988. Catabolic control of mammalian cell culture. Bio/Technology 6: 1041.

7. Kimura, T., Iijima, S., Kobayashi, T. 1987. Effects of lactate and ammonia on the oxygen uptake rate of human cells. J. Ferment. Technol. 65: 341.

8. Lanks, K. 1987. End product of glucose and glutamine metabolism by L929 cells. J. Biol. Chem. 262: 10093.

9. McQueen, A., Bailey, J. E. 1990. Effect of ammonium ion and extracellular $\mathrm{pH}$ on hybridoma cell metabolism and antibody production. Biotechnol. Bioeng. 35: 1067

10. McQueen, A., Bailey, J. E. 1991. Growth inhibition of hybridoma cells by ammonium ion: correlation with effects on intracellular pH. Bioproc. Eng. 6: 49.

11. McQueen, A., Bailey, J. E. 1990. Mathematical modeling of the effects of ammonium ion on the intracellular $\mathrm{pH}$ of hybridoma cells. Biotechnol. Bioeng. 35: 897.

12. Miller, W. M., Wilke, C. R., Blanch, H.W. 1988. Transient responses of hybridoma cells to lactate and ammonia pulse and step changes in continuous culture. Bioproc. Eng. 3: 113.

13. Moolenaar et al. $\mathrm{Na}^{+} / \mathrm{H}^{+}$exchange and cytoplasmic $\mathrm{pH}$ in the action of growth factors in human fibroblasts. Nature 304: 645 .

14. Poole, B., Ohkuma, S. 1981. J. Cell Biol. 90: 665.

15. Reuveny, S., Velez, D., Macmillan, J. D., Miller, L. 1987. Factors affecting monoclonal antibody production in culture. Develop. Biol. Stand. 66: 169.

16. Ryan, W. L., Cardin, C. 1966. Amino acids and ammonia of fetal calf serum during storage. Proc. Soc. Exp. Biol. Med. 123: 27.

17. Ozturk, S. S., Palsson, B. O. 1991. Metabolic, growth, and antibody production kinetics of hybridoma cell culture: I. Analysis of batch reactor operation. Biotechnol. Prog. (to appear).

18. Ozturk, S. S., Palsson, B. O. 1991. Metabolic, growth, and antibody production kinetics of hybridoma cell culture: II. Effects of serum, pH, and dissolved oxygen. Biotechnol. Prog. (to appear).

19. Ozturk, S. S., Palsson, B. O. 1991. Effect of medium osmolarity on hybridoma growth, metabolism, and antibody production. Biotechnol. Bioeng. 37: 989.

20. Ozturk, S.S., Palsson, B. O. 1990. Effect of dissolved oxygen on hybridoma growth, metabolism, and antibody production in continuous culture. Biotechnol. Prog. 6: 437.

21. Ozturk, S.S., Meyerhoff, M., Palsson, B.O. 1989. Measurement of ammonia and glutamine in cell culture media by gas sensing electrodes. Biotechnol. Techn. 3: 217.

22. Thorpe, J. S., Murdin, A. D., Sanders, P. G., Spier, R. E. 1987. The effects of waste products of cellular metabolism on growth and protein synthesis in a mouse hybridoma cell line. Presented at the 194th National Meeting of the American Chemical Society, New Orleans, LA, August 31-September 4.

23. Truskey, G. A., Nicolakis, D. P., Dimasi, D., Haberman, A., Swartz, R.W. 1990. Kinetic studies and unstructured models of lymphocyte metabolism in fed-batch culture. Biotechnol. Bioeng. 36: 797.

24. Van Leuven, F., Cassiman, J.-J., Van Den Berghe, H. 1980. Cell. 20: 37.

25. Visek, W. J., Kolodny, G. M., Gross, P. R. 1972. Ammonia effects in cultures on normal and transformed $3 \mathrm{~T} 3$ cells. J. Cell. Physiol. 80: 373.

26. Zielke, H. R., Sumbilla, C. M., Sevdalian, D. A., Hawkins, R. L., Ozand, P.T. Lactate: a major product of glutamine metabolism by human diploid fibroblasts. J. Cell Physiol. 104: 433 . 